\title{
Water Distribution in the Perspectives of Stakeholders and Water Users in the Tarim River Catchment, Xinjiang, China
}

\author{
Haiyan Peng ${ }^{1}$, Niels Thevs ${ }^{1}$, Konrad Ott ${ }^{2}$ \\ ${ }^{1}$ Institute of Botany and Landscape Ecology, University of Greifswald, Greifswald, Germany \\ ${ }^{2}$ Department of Philosophy, Christian-Albrecht-University Kiel, Kiel, Germany \\ Email: Thevs@uni.greifswald.de
}

Received 20 January 2014; revised 15 February 2014; accepted 11 March 2014

Copyright (C) 2014 by authors and Scientific Research Publishing Inc.

This work is licensed under the Creative Commons Attribution International License (CC BY). http://creativecommons.org/licenses/by/4.0/

(c) (i) Open Access

\section{Abstract}

Many river basins in the arid and semi-arid parts of the world are experiencing water scarcity due to water consumption by agriculture resulting in conflicts between upstream and downstream, conflicts between water users, and degradation of the natural ecosystems. The Tarim Basin, Xinjiang, China, has developed into the world's most important cotton production region with $8.85 \%$ of the world's production. Under the extremely arid climate with annual precipitation of below $100 \mathrm{~mm}$, the water consumption due to irrigation resulted in water scarcity and conflicts between water users as well as between upstream and downstream. The Tarim river catchment harbors about half of the world's Populus euphratica riparian forests, which are impacted by water shortage. Starting in the 1990s, a unified water management system with a quota system for water distribution has been set up. We introduce this unified water management system and analyze how the water distribution works in practice. Ecologists and forestry officials claim more water for environmental flow, whereas water management officials give priority to agricultural, industrial, and domestic water use. The water quotas for downstream regions are frequently not fulfilled, especially during the non-flood season in spring and early summer posing a risk to water users. Water users with financial and political advantages gain more water security than others. The water quotas are annual quotas. These quotas should be differentiated into seasonal quotas, in order to enhance water security for the downstream section of the Tarim all year round.

\section{Keywords}

Water Resource Management, Central Asia, Water Scarcity, Land Use, Cotton, Environmental Flow 


\section{Introduction}

Many river basins in the arid and semi-arid parts of the world are experiencing water scarcity due to water consumption by agriculture resulting in conflicts between upstream and downstream, conflicts between water users, and degradation of the natural ecosystems, such as the Aral Sea Basin [1], Jordan [2], Murray-Darling [3], Yellow River [4], Heihe [5], and Tarim Basin [6] [7]. Given the background of water scarcity, increasing populations, and increasing water demands, water distribution in river basins between upstream and downstream as well as between sectors plays an important role especially for river basins under arid and semi arid climate.

The Tarim Basin, located in the Xinjiang Uyghur Autonomous Region (hereinafter referred to as Xinjiang), China, covers an area of 1.02 million $\mathrm{km}^{2}$, is home to a population of about 9.5 million people, and has turned into the world's most important cotton production region with a total annual cotton lint production of 2.1 million t, i.e. 8.85\% of the world production, in 2010 [8] [9]. In 2011, the share of the cotton lint production in Xinjiang of the worldwide production climbed to 11\% [9] [10]. The catchment of the Aksu and Tarim is the largest river catchment in the Tarim Basin with a river length of $282 \mathrm{~km}$ and $1321 \mathrm{~km}$ of the Aksu and Tarim, respectively [6]. Half of the cotton in the Tarim Basin is produced along the Aksu and Tarim River and most of the population of the Tarim Basin live in the Aksu and Tarim river catchment [8] [11]. Due to the arid climate with an annual precipitation of 30 to $70 \mathrm{~mm}$ in the cropland area along the Aksu and Tarim [7] [12], the cotton production and other agriculture depend on irrigation. The water consumption by irrigation has resulted in periods of water shortage along the midstream and downstream section of the Tarim River during the past ten years [7] [13].

The Tarim Basin also harbors 54\% (352,200 ha) of the world's riparian Populus euphratica Oliv. forests [14]. Those forests form a mosaic of riparian forests, wetlands, shrub vegetation, and small stands of herbaceous vegetation [15] and provide habitat for wildlife [14]. The Populus euphratica forests are the only forests in the Tarim Basin. Those forests and the wetlands are the most productive ecosystems of the drylands in the Tarim Basin [16] [17]. The largest contiguous areas of the Populus euphratica forests with associated wetlands and shrub vegetation are located along the Tarim River in the two nature reserves Tarim Shangyou and Tarim Huyanglin, which stretch along the Tarim River in Xayar County between Aral and Yingbaza and downstream from Yingbaza, respectively [18].

Since 1950, through reclamation of land for irrigated agriculture and rapid population growth, partly driven by resettlement of people from other Chinese provinces to Xinjiang, the water withdrawal from all rivers in the Tarim Basin increased. Until the 1970s, the Aksu, Hotan, and Yarkant River were tributaries, which permanently discharged into the Tarim. From the 1970s onward, the latter two rivers have become disconnected from the Tarim. Also at the beginning of the 1970s, the $320 \mathrm{~km}$ long downstream section and the two terminal lakes Lopnor and Taitema completely fell dry. The natural ecosystems along the whole river, especially along the downstream have been degraded severely [19]-[21].

In order to 1) balance the water use between economic development, mainly agriculture, and ecosystem protection and restoration and 2) pursue a more just water distribution between the Aksu River as tributary and the Tarim upper reaches on one side and the Tarim lower reaches on the other side, a water distribution program which gives water quotas for water users and river stretches was adopted by the Xinjiang Government in 2001 [7] [20]. Similar water quota systems had been adopted along the Yellow River [4] and the Heihe River [5].

While a few studies were directed to characterize the institutional development of water management and legal framework of the water distribution program of the Tarim [20] [22] [23], the current reality of the water allocation and effects on water users on the ground has not been systematically assessed yet. Therefore, this paper aims at revealing the water distribution patterns in the Tarim river catchment from a stakeholder perspective by addressing the following four questions: 1) How is water really distributed among different water use sectors, in particular with regard to environmental flow? 2) How is water distributed among different geographic and administration areas? We focus on the Tarim river catchment, because it is more prone to water shortage compared to the Aksu River [13].

The stakeholder perspective was revealed through semi-structured interviews with experts from governmental administrations, river basin management institutions, scientific research institutions, and local farmers.

The following part (Section 2) will introduce the Tarim Basin and the Tarim river catchment regarding its hydrology, climate, land use, and ecological issues. Afterwards, in Section 3 the institutional framework and the water distribution program along the Tarim River will be presented based on a literature review. Section 4 will present the perspectives of the different stakeholders regarding the water distribution in practise. The role of in- 
stitutions with respect to water distribution is elaborated by interview interpretation and analysis. The paper closes with a discussion and conclusions (Section 5).

\section{The Tarim River Catchment}

\subsection{Geography and Hydrology of the Tarim River Catchment}

The Tarim River flows along the northern rim of the Tarim Basin (Figure 1). Administratively, the Tarim Basin is shared by 5 prefectures (Bayangol, Aksu, Kizilsu, Kashgar, and Hotan) and four divisions of Xinjiang Production Construction Corps (XPCC). The XPCC is a semi-military governmental organization, which was established in 1954, in order to develop remote frontier regions, to promote land reclamation, and to consolidate border defense [24]. The XPCC administers its divisions independently from the prefectural governments. The XPCC is less dependent from the Xinjiang Government compared to the prefectures.

Until the 1970s, the Aksu, Yarkand, and Hotan River permanently supplied water to the Tarim River. The Tarim started at the confluence of these three tributaries at Aral (Figure 1). Today, the Aksu River is the main water source, draining permanently into the Tarim and supplying $73.2 \%$ of total amount of the runoff of the Tarim. The Hotan River and the Yarkant River supply 23.2\% and 3.6\% in average, respectively, and reach Aral only during flood events [6] [7]. The Konqi River (lower part of the Kaidu-Konqi River), which drains the Bosten Lake and which flows parallel to the Tarim lower reaches, was hydrologically connected with the Tarim through natural wetlands and river branches until the 1970s. Today, it supplies water through artificial channels into the Tarim downstream section. The three tributaries of the Tarim as well as all other rivers of the Tarim Basin originate in the mountain ranges, which surround the Tarim Basin, i.e. Tianshan, Karakoram, Kunlun and Altun. The central part of the basin is occupied by the Taklamakan Desert [20].

The Aksu, Hotan, Yarkant, and Kaidu-Konqi River as source streams, together with the Tarim mainstream constitute the Tarim river catchment or the so-called four source streams and one mainstream area (Figure 1). This area is the scope of the Tarim Water Distribution Program. It has a surface of 0.26 million $\mathrm{km}^{2}$, accounting $25.4 \%$ of the whole Tarim Basin; the total average annual runoff of the four source rivers (including the Konqi) is $25.67 \mathrm{~km}^{3}$, accounting for $64.4 \%$ of the whole Tarim Basin [7]. The particular study area of this paper is the Tarim river catchment, i.e. the Tarim mainstream sub-basin in Figure 1.

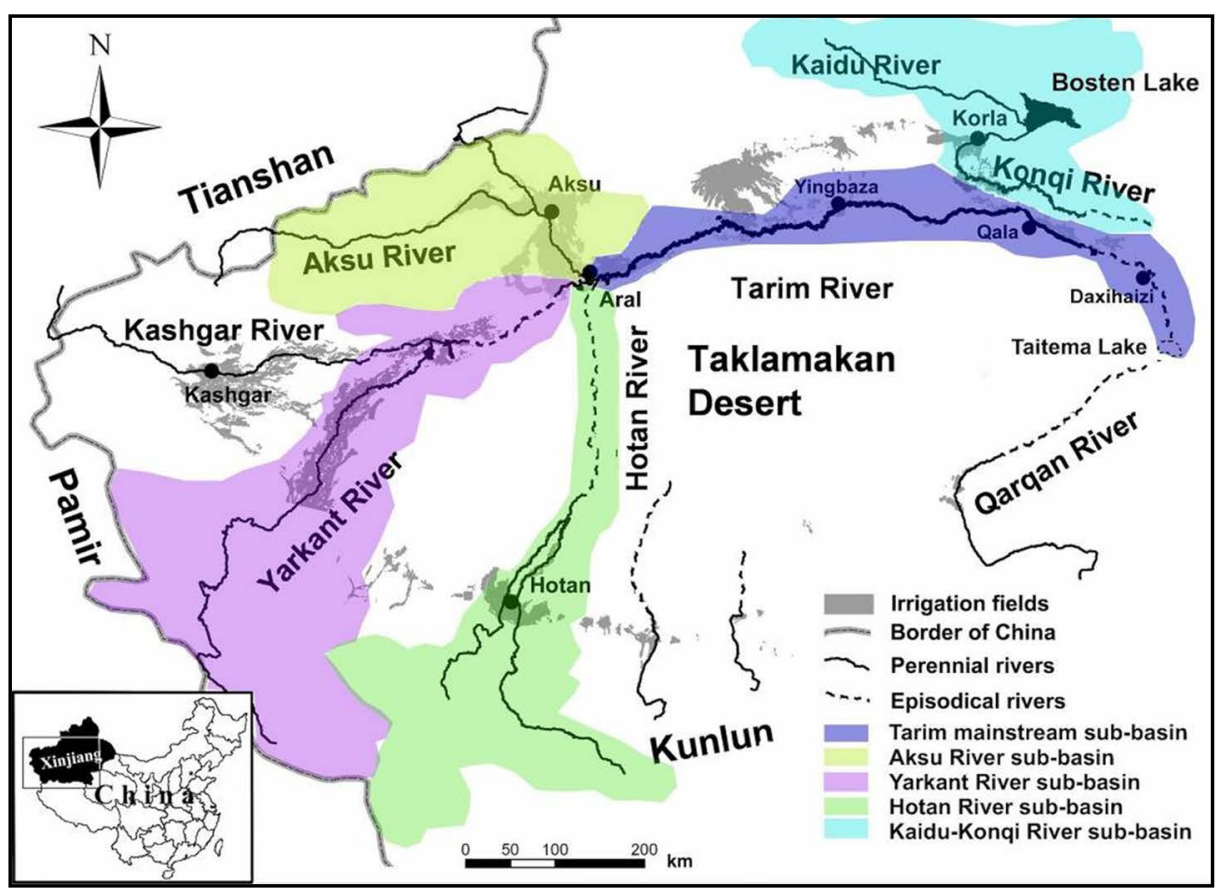

Figure 1. Map of the Tarim Basin and the Tarim river catchment (the so-called four source streams and one mainstream area) with the five sub-catchments Aksu, Yarkant, Hotan, KaiduKonqi, and Tarim, after [13] and [25]. 
The climate in the Tarim Basin is extremely arid and continental [26] [27]. The annual precipitation in the Tarim river catchment ranges from 30 to $70 \mathrm{~mm}$, whereas the annual potential evaporation ranges from 2100 to $3000 \mathrm{~mm}$ [28]. So, the only water source for natural ecosystems and agriculture is river water. The water supply for the rivers in the Tarim Basin is constituted of melting water from glaciers and snow as well as rainwater from the surrounding mountains. Therefore, the river runoff is concentrated in the period from June to September, amounting to $60 \%-80 \%$ of the annual runoff, while there is only $10 \%$ of the annual runoff from March to May [6] [7] [20].

Once the rivers flow out of the mountains, they turn into losing streams, i.e. they do not receive water, but constantly drain water into the groundwater layer and thus become smaller and smaller. The mainstream of the Tarim River is $1321 \mathrm{~km}$ long, which is divided into the upper reaches with a length of $495 \mathrm{~km}$ (Xiaojiake (close to Aral)—Yingbaza), the middle reaches with $398 \mathrm{~km}$ (Yingbaza—Qala), and the lower reaches with $428 \mathrm{~km}$ (Qala_-Taitema Lake) [6]. Along the middle reaches the Tarim River formed an inland delta, which was about $100 \mathrm{~km}$ wide near today's Yingbaza. River branches of this inland delta also connected to the Konqi River [29].

\subsection{Economic Development and Ecological Problems in the Tarim River Catchment}

The population along the Tarim mainstream has increased from about 0.5 million in 1957 to about 2 million in 2002 [21]. A prognosis provided by [7] states that the population growth rate will be $10.13 \%$ from now until the year of 2020. The primary industry (i.e. farming, forestry, animal husbandry, and fishery) predominates the economy in the whole Tarim Basin, contributing to $46 \%$ of the regional Gross Domestic Product (GDP) [20]. Thereby, cotton agriculture contributes the largest share to the regional GDP. Cotton has become the major crop in the Tarim Basin since the 1990s. While Xinjiang provided only 2.5\% of China's total cotton production in 1978, today about one third of China's cotton production comes from Xinjiang [10] [30].

The area of irrigated land increased all over the Tarim Basin, from 706,000 ha in 1949 over 1,330,000 ha in 1980 to $1,412,000$ ha in 1990 [31] and 1,650,000 ha in 2008 [8].

Due to the increased irrigation demands, the water resources along the Tarim River have been reduced. Until ten years ago, the water use efficiency of irrigation in the Tarim Basin ranges between $35 \%$ and $40 \%$ [19]. In 1972, the Daxihaizi Reservoir (Figure 1) was constructed. This reservoir cut off the $320 \mathrm{~km}$ of the Tarim downstream of Daxihaizi so that this river stretch fell completely dry. The end-lake of the Tarim River, the Lop Nor, comprising an area of $100 \mathrm{~km}^{2}$ in the 1950s, disappeared entirely in the early 1970s. The other terminal lake, Taitema Lake; dried up soon afterwards [6] [19]. The salt content of the surface waters and the groundwater has increased due to drainage waters from the irrigation. During the process of land reclamation, farmers and herders already had to give up agricultural land, because they suffered from water shortage and soil salinization [32]. Natural ecosystems have been degraded, especially along the Tarim lower reaches and the rim of the inland delta along the Tarim middle reaches [6].

The natural ecosystems form a mosaic of riparian forests, wetlands and reed beds, and shrub vegetation. The riparian forests consist of Populus euphratica and on smaller areas of $P$. pruinosa. The wetlands and reed beds are dominated by Phragmites australis. The shrub vegetation consists of Tamarix stands and halophytes [15]. Most of the species of those natural ecosystems are so-called phreatphytes. They exploit the groundwater and thus adapt to the arid climate [33], e.g. P. euphratica is able to tap the groundwater to depths of $10 \mathrm{~m}$ [15].

\section{The Water Distribution Program in the Tarim River Catchment}

\subsection{Water Management at the Tarim River}

Until the end of the $20^{\text {th }}$ century, there was no unified water management plan for the Tarim river catchment [20] [34]. The water allocation along all rivers in the Tarim Basin was administered separately by prefectures and divisions of XPCC. Thus, the prefectures and divisions of XPCC competed for water. Within each administrative area, water was diverted according to local demands for irrigation not considering the needs of downstream water users.

Conflicts among administrative areas and individual water consumers, as well as the degradation of the natural ecosystems attracted concerns from the Central Government of China and international institutions. Thus, a comprehensive investigation on water resources and their consumption was carried out in the Tarim Basin during 1975-1982. Since then, an overall plan for a unified water management (UWM) in the entire river basin has 
been suggested and discussed [20].

In 1992, the Tarim Basin Management Bureau (TMB) was established to manage the overall water resources of the Tarim Basin. Afterwards, in 1997 the Tarim Basin Water Resources Commission (TWRC) was established, in order to guide and supervise the water management in the whole Tarim Basin and Tarim river catchment [35]. From 1991 to 2005, the two World Bank projects Tarim Basin Project (1991-1997) and Tarim Basin II Project (1998-2005) were carried out, supporting constructions of a more solid infrastructure for irrigation agriculture, increasing efficiency of water and land resource management, and improving the administration structures in the Tarim Basin [36].

In 2001, the State Council adopted the Near-Future Comprehensive Management Program of the Tarim Basin [37]. The overarching aim of this program is to protect and partly restore natural ecosystems along the middle and lower reaches of the Tarim River and restore the terminal lake Taitema by guaranteeing a minimum annual amount of water flowing through the Tarim lower reaches downstream of Daxihaizi. A national investment of 10.7 billion CNY (about 1.69 billion US dollars) was allocated for this program from 2001 to 2011. This program focuses on the Tarim river catchment and comprised a bundle of measures: 1) Transfer of water from the neighboring Kaidu-Konqi River catchment into the Tarim lower reaches downstream of the Daxihaizi Reservoir, 2) construction of dykes along the Tarim middle reaches downstream of Yingbaza, in order to channel the water downstream instead of sustaining the inland delta along the middle reaches, 3) propagation of water saving irrigation techniques, and 4) setting up an integrated and fair water distribution program. Two channels from the Konqi River to the Tarim lower reaches were opened by 2004. The lateral dykes along the Tarim middle reaches were completed by 2005. Drip irrigation has been propagated and is used on the majority of cotton fields. The Taitema Lake has reappeared after 30 years varying in size (maximum area was $200 \mathrm{~km}^{2}$ ) according to the runoff from the Tarim downstream section. But though this water management program is in place, the Tarim River ceased to flow on more than half of its total river length during spring and early summer 2004, 2007, 2008, and 2009 resulting in crop failures downstream [13].

In 2005, the government of Xinjiang issued two official documents: Scheme of Surface Water Distribution in the Tarim Basin (Four Source Streams and One Mainstream) and Management Methods of Water Dispatching in the Tarim Basin (Four Source Streams and One Mainstream). These two documents announced the establishment of the governmental Tarim Water Distribution Program for the Tarim river catchment, which is introduced underneath [38] [39].

\subsection{The Tarim Water Distribution Program}

The Tarim Water Distribution Program distinguishes three basic water use sectors: production (agricultural and industrial production), domestic water consumption, and environmental flow. Within the sector production irrigated agriculture (mainly cotton) consumes most water. Figure 2 shows the annual water demands of these three sectors as planned to be implemented in the Tarim Water Distribution Program. These numbers refer to the water demands of the four source steams and one mainstream area, i.e. along the rivers Aksu, Yarkant, Hotan, Konqi, and the Tarim proper [7].

Based on the water demands, within the Tarim Water Distribution Program a water quota system has been designed with detailed water quotas for each tributary, the Tarim mainstream, and the administrative areas. First, quotas were made, which determine the amount of annual water release from the tributaries to the Tarim mainstream under average conditions: $3.42 \mathrm{~km}^{3} / \mathrm{a}$ stem from the Aksu River, $0.90 \mathrm{~km}^{3} / \mathrm{a}$ from the Hotan River, and $0.33 \mathrm{~km}^{3} / \mathrm{a}$ from the Yerkant river, which sum up to $4.65 \mathrm{~km}^{3} / \mathrm{a}$ at Aral. Additionally, a quota of $0.45 \mathrm{~km} 3 / \mathrm{a}$ from the Kaidu-Konqi River to be released to the Tarim at Qala was fixed (Table 2 and Figure 3). Secondly, water quotas were set for the administration areas. Table 1 shows the water quotas for Aksu Prefecture and Division 1 of XPCC along the Aksu River. Under average conditions, which means an annual inflow of $8.06 \mathrm{~km}^{3}$ into the Aksu River, the water consumption along the Aksu River amounts to $4.64 \mathrm{~km}^{3} / \mathrm{a} .2 .54 \mathrm{~km}^{3} / \mathrm{a}$ are diverted into Aksu Prefecture, while $2.11 \mathrm{~km}^{3} / \mathrm{a}$ are diverted into Division 1 of XPCC (Table 1 ). Subsequently, $3.42 \mathrm{~km}^{3} / \mathrm{a}$ of water are to be released into the Tarim mainstream at the Aral Gouging station (Table 1, Table 2 and Figure 3). Similar water quota regulations are also applied for the Yerkant and Hotan River [38].

Water quotas for the Tarim mainstream are more detailed regarding the water use of different sectors. During the period from 1957 to 2000, the maximum annual water inflow at Aral Station was $6.96 \mathrm{~km}^{3} / \mathrm{a}$, while the minimum was $2.56 \mathrm{~km}^{3}$ a. Therefore, ten water allocation keys were developed (Table 2) for the Tarim main- 


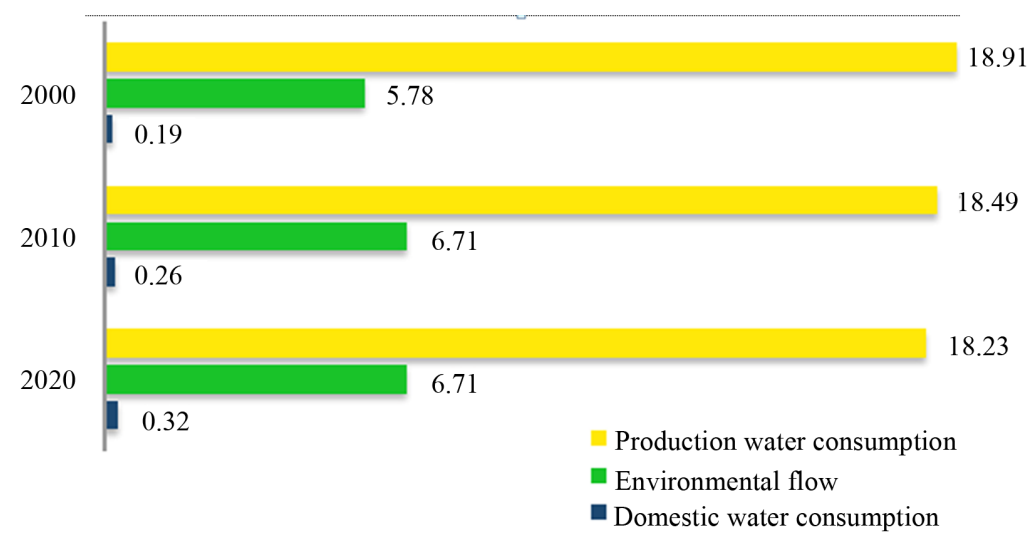

Figure 2. Planned water demands for production (agricultural and industrial production), domestic water consumption, and environmental flow [ $\left.\mathrm{km}^{3} / \mathrm{a}\right]$ for the Tarim river catchment and the tributaries' catchments (Aksu, Yarkant, Hotan, Konqi) [7].

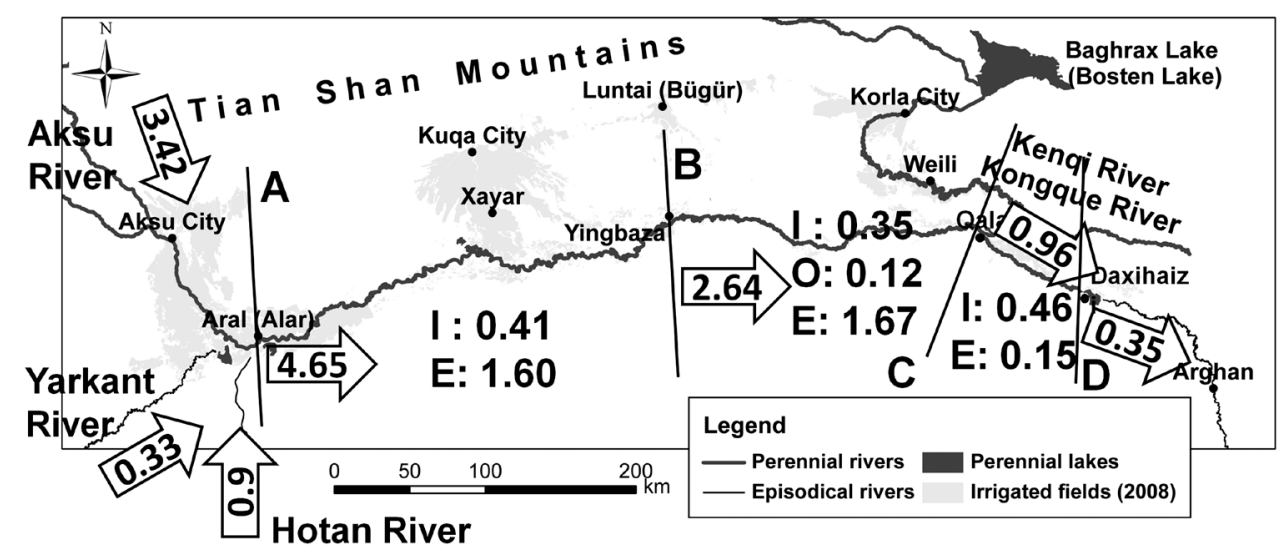

Figure 3. Water inflow from the tributaries Aksu, Yarkant, and Hotan into the Tarim mainstream and water quotas along the Tarim mainstream under average conditions [ $\left.\mathrm{km}^{3} / \mathrm{a}\right]$, after [13]. Note: I: irrigation and industry, E: environmental flow, O: oil exploitation. A-B: upper reaches, B-C: middle reaches, C-D: upper section of lower reaches, $\mathrm{D}$ and below: lower reaches.

Table 1. Annual water quotas within the Tarim Water Distribution Program under average conditions along the Aksu River [km³/a] as the major tributary to the Tarim mainstream [7].

\begin{tabular}{|c|c|c|c|c|}
\hline \multirow{2}{*}{$\begin{array}{l}\text { Inflow of headwaters } \\
\text { into Aksu River }\end{array}$} & \multicolumn{3}{|c|}{ Water consumption along Aksu River } & \multirow{2}{*}{$\begin{array}{l}\text { Water release into } \\
\text { Tarim mainstream }\end{array}$} \\
\hline & $\begin{array}{l}\text { Sum of water } \\
\text { consumption }\end{array}$ & $\begin{array}{c}\text { Aksu } \\
\text { Prefecture }\end{array}$ & $\begin{array}{l}\text { Division } 1 \\
\text { of XPCC }\end{array}$ & \\
\hline 8.06 & 4.64 & 2.54 & 2.11 & 3.42 \\
\hline
\end{tabular}

stream varying from an annual inflow of $2.5 \mathrm{~km}^{3} / \mathrm{a}$ to $7.0 \mathrm{~km}^{3} / \mathrm{a}$ at Aral. When, for example, an average annual inflow at Aral Station is forecasted $\left(4.65 \mathrm{~km}^{3} / \mathrm{a}\right)$, the annual water quota for upper reaches of the Tarim mainstream shall be $2.01 \mathrm{~km}^{3} / \mathrm{a}$ in total with $0.41 \mathrm{~km}^{3} / \mathrm{a}$ allocated for production and domestic use, and $1.60 \mathrm{~km} / \mathrm{a}$ for environmental flow. The boundary between upper and middle reaches is also the boundary between the Aksu Prefecture and Bayangol Prefecture. Thus, the quota for the upper reaches of the Tarim is equivalent to the quota for Aksu Prefecture along the Tarim River [38].

Under such average conditions, $2.64 \mathrm{~km}^{3} / \mathrm{a}$ water shall reach Yingbaza and thus shall be released into the middle reaches (Figure 3), The annual water quota for the middle reaches until Qala shall be $2.14 \mathrm{~km}^{3}$ in total, 
Table 2. Annual water quotas $\left[\mathrm{km}^{3} / \mathrm{a}\right]$ fixed within the Scheme of Surface Water Distribution for water withdrawal for economic activities and environmental flow along the upper, middle, and lower reaches of the Tarim River starting in Aral, i.e. at the confluence of the three tributaries Aksu, Yarkant, and Hotan. The column in light gray refers to the average conditions [7]. The term economic activities refer to irrigation, industrial, and domestic water consumption (i.e. sum of production and domestic use).

\begin{tabular}{|c|c|c|c|c|c|c|c|c|c|c|c|}
\hline River section and water user & \multicolumn{11}{|c|}{ Annual runoff $\left[\mathrm{km}^{3} / \mathrm{a}\right]$} \\
\hline \multicolumn{12}{|l|}{ Upper reaches } \\
\hline Inflow at Aral & 2.50 & 3.00 & 3.50 & 4.00 & 4.50 & 4.65 & 5.00 & 5.50 & 6.00 & 6.50 & 7.00 \\
\hline Economic activities & 0.37 & 0.37 & 0.37 & 0.41 & 0.41 & 0.41 & 0.41 & 0.41 & 0.41 & 0.41 & 0.41 \\
\hline Environmental flow & 0.72 & 0.93 & 1.15 & 1.32 & 1.54 & 1.60 & 1.76 & 1.97 & 2.19 & 2.40 & 2.62 \\
\hline Runoff released into middle reaches & 1.42 & 1.70 & 1.99 & 2.27 & 2.56 & 2.64 & 2.84 & 3.12 & 3.41 & 3.69 & 3.97 \\
\hline \multicolumn{12}{|l|}{ Middle reaches } \\
\hline Runoff at Yingbaza & 1.42 & 1.70 & 1.99 & 2.27 & 2.56 & 2.64 & 2.84 & 3.12 & 3.41 & 3.69 & 3.97 \\
\hline Oil exploitation & 0.12 & 0.12 & 0.12 & 0.12 & 0.12 & 0.12 & 0.12 & 0.12 & 0.12 & 0.12 & 0.12 \\
\hline Other economic activities & 0.30 & 0.30 & 0.30 & 0.35 & 0.35 & 0.35 & 0.35 & 0.35 & 0.35 & 0.35 & 0.35 \\
\hline Environmental flow & 0.73 & 0.95 & 1.18 & 1.37 & 1.60 & 1.66 & 1.83 & 2.06 & 2.29 & 2.51 & 2.74 \\
\hline Runoff released into lower reaches & 0.27 & 0.33 & 0.38 & 0.43 & 0.49 & 0.51 & 0.54 & 0.60 & 0.65 & 0.71 & 0.76 \\
\hline \multicolumn{12}{|l|}{ Lower reaches } \\
\hline Water transferred from Konqi River & 0.45 & 0.45 & 0.45 & 0.45 & 0.45 & 0.45 & 0.45 & 0.45 & 0.45 & 0.45 & 0.45 \\
\hline Runoff at Qala Station & 0.72 & 0.78 & 0.83 & 0.88 & 0.94 & 0.96 & 0.99 & 1.05 & 1.10 & 1.16 & 1.21 \\
\hline Economic activities & 0.41 & 0.41 & 0.41 & 0.46 & 0.46 & 0.46 & 0.46 & 0.46 & 0.46 & 0.46 & 0.46 \\
\hline Environmental flow & 0.09 & 0.10 & 0.12 & 0.12 & 0.14 & 0.15 & 0.17 & 0.21 & 0.24 & 0.28 & 0.31 \\
\hline $\begin{array}{l}\text { Runoff released into the lower } \\
\text { reaches below Daxihaizi }\end{array}$ & 0.23 & 0.26 & 0.30 & 0.31 & 0.34 & 0.35 & 0.36 & 0.38 & 0.40 & 0.42 & 0.44 \\
\hline
\end{tabular}

with $0.35 \mathrm{~km}^{3}, 0.12 \mathrm{~km}^{3}$, and $1.66 \mathrm{~km}^{3}$ allocated for irrigation agriculture, oil industry, and environmental flow, respectively. This river stretch lies within Bayangol Prefecture. Therefore, this water quota is equivalent to the water quota for Bayangol [7] [38].

The remaining $0.51 \mathrm{~km}^{3} / \mathrm{a}$, together with $0.45 \mathrm{~km}^{3} / \mathrm{a}$ carried through channels from the Konqi River, shall be released from the Qala Gauging Station to the lower reaches (Figure 3). Along the river stretch from the Qala Gauging Station to the Daxihaizi Reservoir, $0.46 \mathrm{~km}^{3} / \mathrm{a}$ and $0.15 \mathrm{~km}^{3} / \mathrm{a}$ are allocated for production (including domestic use) and environmental flow, respectively. Between Qala and Daxihaizi, most of the land lies within the Division 2 of XPCC so that this water quota is equivalent to the quota for the Division 2 of XPCC. Finally, $0.35 \mathrm{~km}^{3} / \mathrm{a}$ of water shall be released from the Daxihaizi Reservoir into the lower reaches as environmental flow towards the Taitema Lake, which is the current terminal lake of the Tarim River [7] [38] [39].

The Tarim Water Distribution Program grants a constant water amount for agriculture along all sections of the Tarim River. The water amount for agriculture drops slightly only below an annual inflow of $4 \mathrm{~km}^{3}$ at Aral (Table 2). A nearly constant amount of water $(0.12 \mathrm{~km} 3 / \mathrm{a})$ is guaranteed to the oil exploitation along the Tarim middle reaches over the whole range of annual runoff The water which exceeds the amounts granted to economic activities is released for the natural ecosystems, i.e. constitutes the environmental flow. The environmental flow thus varies considerably depending on the inflow into the Tarim River (Table 2).

The hydrological year for the Tarim river catchment starts by October and lasts until September of the following year. During winter, an annual inflow for the current hydrological year is estimated. Based on this estimate, annual water quotas for each river stretch and administrative area are set according on Table 2. Finally, contracts on these water quotas and management provisions are signed between the representative of TWRC and representative of each administrative area [39]. 
The hydrological year splits into a so-called non-regulating period, i.e. from October to June (which is usually non-flooding seasons) and a so-called regulating period i.e. from July to September (which is usually flooding seasons). Right before the beginning of regulating period, the water consumption is calculated, which has been realized by each administrative area so far during the non-regulating period. This amount of water is deducted from the total annual water quota. The remaining water quota is allocated during the regulating period. During the regulating period monitoring and adjusting on water release and diversion are conducted every ten days. During the non-regulating period from October through winter and spring until June no monitoring takes place.

\subsection{Institutional Arrangements}

According to the Water Law of China [40], water resources are national properties and the state has the responsibility to administer and protect them. Thus, the water resources of the Tarim river catchment are under the overall responsibility of the Xinjiang Government. The TWRC, established as the agency of the regional government, takes full responsibility to administer and protect the water resources in the Tarim river catchment. Figure 4 shows the decision-making structure of water management in the Tarim River.

The Standing Committee of TWRC is the decision-making body with the following members [41] [42]: ViceGovernor of Xinjiang, representatives of relevant administrations on the provincial level (administrations of water, agriculture and land management, environment, finance and planning), directors of the five prefectures (Bayangol, Aksu, Kizilsu, Kashgar, and Hotan Prefectures) and directors of XPCC's Water Resource Bureau and XPCC's four divisions (Division 1, 2, 3, and 14 of XPCC). It is important to note that the local governments within the XPCC also participate in the management of water resources of the Tarim river catchment, though the XPCC has its own governmental system independent from the Government of Xinjiang, The director of the XPCC's Water Resource Bureau and the directors of the four divisions are commissioners of the TWRC as stated in the Charter of TWRC from 1999 [41].

The TMB, as the administrative and technical agency of TWRC, is the main executive body of the development, utilization, protection, and management of water resources of the Tarim river catchment.

\section{Stakeholder Perspectives on the Water Allocation in the Tarim River Catchment}

Semi-structured interviews were conducted with 27 exports from governmental administrations (water, agriculture, forest, and pasture at provincial, prefectural, and county levels), river basin management institutions, scientific research institutions and local farmers, in order to investigate the perspectives of different stakeholders with regard to the implementation of the water distribution program. The interviews covered all cities and counties,
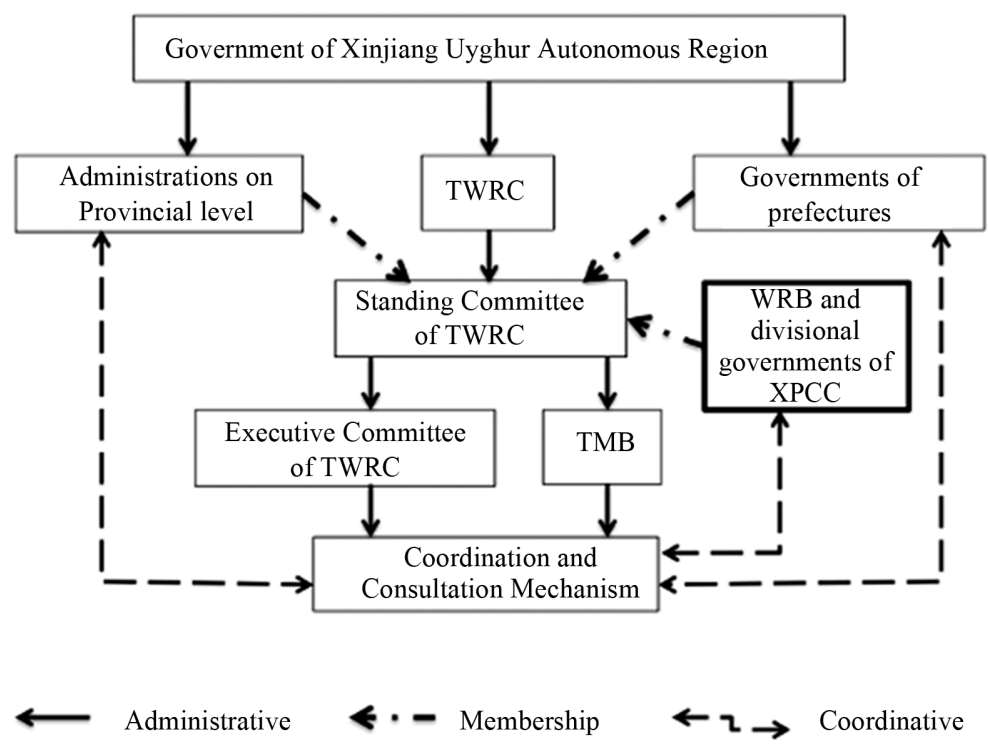

Figure 4. The decision-making structure of water management in the Tarim river catchment, based on the Charter of [20] [41]. 
which divert water directly from the Tarim mainstream: Aksu City, Aral City, Shaya County, Korla City, Yuli County, and XPCC.

\subsection{Stakeholders' Perspectives on the Water Distribution System}

The interviews with regard to stakeholders' perspectives on the water distribution system covered the following topics: 1 implementation of the Tarim Water Distribution Program, 2) water distribution between economic activities and environmental flow, 3) water allocation between administrative areas, 4) situation of the natural riparian ecosystems, and 5) evaluation of the water transfer from the Konqi River to the Tarim lower reaches as well as the construction of dykes along the Tarim middle reaches.

With respect to an overall evaluation of the Tarim Water Distribution Program four stakeholders stated that the Tarim Water Distribution Program and its implementation were good, while three stakeholders stated that both were not good. Five stakeholders replied that the Tarim Water Distribution Program was well designed, but its implementation had short comings. The number of respondents to this question was low, because only interviewees from TMB and Xinjiang Water Resource Bureau gave clear statements. All others did not have any clear knowledge about the content of the Tarim Water Distribution Program. Some stakeholders did not reply, because they did actually do not even know that the Tarim Water Distribution Program existed.

In response to the question of water distribution between water use sectors, the opinions were summarized as follows: The TMB, as the top management organization of water resources in the Tarim river catchment and the whole Tarim Basin, stated that the three purposes of water use should follow the order: priority on domestic water use, afterwards water use for production, and the remaining water is left for environmental flow. Theoretically, the water quotas for environmental flow should be guaranteed. But, in practice water first shall be used to meet the demands of all economic activities. The remaining water can be released as environmental flow for natural ecosystems. The opposite opinion was stated by ecologists and forestry officials. They claimed that water use for agriculture and other economic activities should be limited, while environmental flow should be increased.

Responding to the question of water distribution between different administrative areas, five stakeholders agreed that the water distribution between different areas was fair and equal. These stakeholders gave the following reasons: 1) the water quotas were made based on scientific research, 2) all stakeholders agreed on this water distribution plan; and 3) TMB was not a benefit holder but a manager. Five stakeholders replied that the water quotas for different areas in theory were fair, however, the implementation was difficult due to management problems and resulted in periods of water shortage. The two stakeholders Water Resource Bureau of Yuli County (lower reaches) and Aksu Management Bureau (Aksu River) responded that the distribution between the different areas was unfair.

The Water Resource Bureau of Yuli County stated that the water distribution was unfair, because 1) most of the time the lower reaches received less water than their respective water quotas and 2) part of the Konqi River water was diverted to the Tarim River, while in the near past the Konqi River was not a tributary of the Tarim and only flew through Yuli County. This water transfer, which the Water Resource Bureau of Yuli County referred to, was explained in Figure 3 and Table 2.

The Aksu Management Bureau responded, too, that the water allocation between administrative areas was unfair. The reasons given by the Aksu Management Bureau were: 1) about 66,700 ha agriculture land of Aksu Prefecture were not considered in the Water Distribution Program and 2) the water quota for Division 1 of XPCC was separated from Aksu Prefecture, 3) there was no quota for environmental flow in the program for the Aksu River, though Aksu Prefecture had obligations to preserve existing riparian ecosystems, and 4) the development of Aral City may take away water from Aksu Prefecture. Aral became a separate administrative unit in 2009. Before, it was part of division 1 of the XPCC.

Regarding the current situation of the natural ecosystems, the Xinjiang Water Resource Bureau, again, was the only institution, which claimed that the natural ecosystems were recovering all over the Tarim river catchment. However, one stakeholder at the middle reaches and another at the lower reaches claimed that the natural ecosystems inside the dykes were recovering, while the natural ecosystems outside the dykes degraded since the dykes had been constructed. Generally, interviewees from academic institutions and stakeholders located at the lower reaches stated that the natural ecosystems were further degrading.

Regarding the construction of dykes along the Tarim middle reaches, interviewees from academic institutions 
complained about the necessity of this project and stated that the dykes hampered seed germination of Populus euphratica, which was the key-stone species of the riparian forests in the Tarim Basin. Major river branches of the inland delta of the Tarim middle reaches were connected to the Tarim through locks in the dyke. But the locks were opened only for short times so that the river branches carried water for short time periods. The groundwater was refilled only during short times so that the groundwater levels behind the dykes dropped and the vegetation degraded.

Stakeholders from Bayangol Prefecture at the lower reaches of the Tarim River claimed that it was unfair to transfer water from the Konqi River to the Tarim lower reaches, because the Konqi River was not a natural tributary river of the Tarim River anymore. However, Xinjiang Water Resource Bureau, as the only institution holding a positive attitude towards the project, claimed that the water transfer was designed according to the governmental water distribution plan in order to transport water more efficiently and that it was based on scientific research results.

\subsection{The Role of Institutions in Water Distribution in Stakeholders' Perspective}

Regarding the role of the institutions from the field of water distribution, opinions were collected with respect to three aspects: 1) functions and influences of laws on water distribution; 2) cooperation and interaction between institutions of different levels and from different administration areas; 3) status of public participation in the decision-making process and protection of the rights of local people.

Most interviewees did not reply to the questions about functions and influences of laws on water distribution. One interviewee from the academia pointed out that the current water laws did not entitle people water rights. Moreover, there were no clearly defined punishments for those administrative areas which used more water than granted by the quota system. An interviewee from Xinjiang University thinks that the water distribution program was not implemented according to the distribution plan but according to the person who was implementing it. A number of interviewees expressed their disappointment on the law enforcement.

At the time of the interviews, the Management Bureaus of the tributaries were merged into the TMB. This institutional reform faced many difficulties and the cooperation efficiency was low, because the Management Bureaus of the tributaries used to act rather independently from the TMB. Further conflicts existed between the agriculture and forest administrations, and between institutions from upper reaches and lower reaches. Cooperation between administrative and academic institutions was not well developed. Administrative institutions at local level complained that they had no power to rule affairs within their own administration area, instead they had to report the problems to TMB and wait for replies, which made the management very inefficient.

Most interviewees also did not reply to the question about public participation in the decision-making process and protection of the rights of local people. Those who replied stated that farmers and animal herders had no channel to participate in the decision making processes.

\section{Discussion and Conclusions}

At the Tarim River and its tributaries a water quota system, the Tarim Water Distribution Program, was set up in a top-down approach, similar to the Yellow River [4] and the Heihe River [5], both in China. In spite of the Tarim Water Distribution Program and its water quotas along the Tarim River, the interview results indicate ongoing conflicts between water using sectors as well as between upstream and downstream.

The water amounts stated in the Tarim Water Distribution Program as listed in Table 2 and shown in Figure 3 are annual amounts. Though, the runoff of the Tarim River is concentrated between July and September, while the water demand for irrigation of cotton starts to increase in May when cotton enters the development stage [43] [44]. Thus, the spring time and early summer poses a bottle neck for the water distribution. During this time of the year water users along the Aksu and Tarim upstream withdrawal water from the river according to their demand so that the Tarim may run dry as in 2004, 2007, 2008, and 2009 [13]. Afterwards, during the flood season, in most years there is more water than the irrigation and oil exploitation can use. This water constitutes the largest share of the environmental flow.

During the bottleneck period in spring and early summer, no monitoring of water withdrawal takes place, because this is the so-called non-regulating period. The regulating period with regular monitoring falls into the time, when the Tarim River carries flood. The absence of monitoring of water withdrawal during the bottleneck period in spring and early summer, coupled with partly weak implementation of the Tarim Water Distribution 
Program, may explain water allocation below the quotas as stated by water users downstream. Under the current situation, the water users along the middle and lower reaches bear a high risk of losing their crop due to water shortage in early summer. In order to reduce this risk, farmers and villages invest in groundwater wells, which exploit fossil groundwater [13]. Water users with financial and political advantages gain more water security than others. The annual water quotas should be further differentiated into seasonal quotas, which are also monitored during spring, in order to reduce the risk losing their crops and reduce the investment burden for water users downstream. So, the so-called non-regulating period should be abolished.

According to the Tarim Water Distribution Program, first the lower reaches downstream Daxihaizi shall be served at the cost of the middle reaches. But, water shortages outside the dykes along the middle reaches impact on the two nature reserves Tarim Huyanglin and Shaya Talimu Shangyou. Through the dykes and land use, the part of the Tarim Huyanglin Nature Reserve, which still contains near natural riparian ecosystems and which has the potential to protect the riparian ecosystems, including its ecosystem processes, shrunk from $120 \mathrm{~km}$ river length to a river stretch of $25 \mathrm{~km}$ [15] [45]. In terms of area and in terms of completeness of ecosystem processes, the riparian vegetation preserved along the Tarim lower reaches does not compensate for this impact along the middle reaches.

With respect to institutional settings and public participation, the following suggestions are proposed: 1) The awareness for the significance of ecosystem protection and for the relevant laws and regulations should be increased. 2) Changes should be made in the administrative system, in order to improve the efficiency of institutional cooperation. 3) Efforts should be made to improve the legislation situation. Laws and regulations should be strictly enforced in order to implement the water distribution program. The rights of participation should be guaranteed by law, as it is essential to ensure justice in the field of distribution of public goods. 4) It should be considered to establish a water market. Under a water market, it must be ensured that poor people still have access to water. Water is crucial for all human activities so that water distribution should not favour the advantaged water users.

\section{Acknowledgements}

We express our thanks to the Stemmler-Foundation within the German Science Centre, which granted the Master Course Scholarship to Haiyan Peng. Furthermore, we thank the Ministry of Education and Science of Germany as well as the Robert-Bosch-Foundation for providing additional travel funds for the field work.

\section{References}

[1] ICWC (Interstate Commission for Water Coordination of Central Asia) (1992) Agreement of Five Central Asian States. http://www.icwc-aral.uz/statute1.htm

[2] GLOWA Jordan River (2008) An Integrated Approach to Sustainable Management of Water Resources under GlobalChange. http://www.glowa-jordan-river.de/

[3] Murray Darling Basin Commission (2006) Murray Darling Basin Agreement. http://www.comlaw.gov.au/Details/C2011C00160/Html/Text\#_Toc289261269

[4] Zhu, Z.P., Giordano, M., Cai, X.M., Molden, D., Hong, S.C, Zhang, H.Y., Lian, Y., Li, H., Zhang, X.C., Zhang, X.H. and Xue, Y.P. (2003) Yellow River Comprehensive Assessment: Basin Features and Issues, IWMI and YRCC. http://www.iwmi.cgiar.org/Publications/Working Papers/working/WOR57.pdf

[5] Chen, Y., Zhang, D.Q., Sun, Y.B., Liu, X.N., Wang, N.Z. and Savenje, H.H.G. (2005) Water Demand Management: A Case Study of the Heihe River Basin in China. Integrated Water Resource Assessment, 30, 408-419.

[6] Song, Y.D., Fan, Z.L., Lei Z.D. and Zhang F.W. (2000) Research on Water Resources and Ecology of Tarim River, China. Xinjiang People's Press, Urumqi.

[7] Tang, D.S. and Deng, M.J. (2010) On the Management of Water Rights in the Tarim Basin. China Water Power Press, Beijing.

[8] Xinjiang Statistics Bureau (2010) Xinjiang Statistical Yearbook of 2010. China Statistics Press, Beijing.

[9] FAOSTAT (2013) http://faostat.fao.org/

[10] USDA (2012) China-Peoples Republic of Cotton and Products Annual. GAIN Report Number: CH12031. http://www.thefarmsite.com/reports/contents/chinacotmay12.pdf

[11] Feike, T., Mamitimin, Y., Li, L., Abdusalih, N. and Doluschitz, R. Development of Agricultural Land and Water Use and Its Driving Forces in the Aksu-Tarim Basin, P.R. China. Environmental Earth Science. 
[12] Liu, M.G. (1997) Atlas of Physical Geography of China, China Map Press, Beijing.

[13] Thevs, N. (2011) Water Scarcity and Allocation in the Tarim Basin: Decision Structures and Adaptations on the Local Level. Journal of Current Chinese Affairs, 3, 113-137.

[14] UNESCO (2010) Taklimakan Desert-Populus euphratica Forests. http://whc.unesco.org/en/tentativelists/5532/

[15] Thevs, N., Zerbe, S., Peper, J. and Succow, M. (2008) Vegetation and Vegetation Dynamics in the Tarim River FloodPlain of Continental-Arid Xinjiang, NW China. Phytocoenologia, 38, 65-84. http://dx.doi.org/10.1127/0340-269X/2008/0038-0065

[16] Thevs, N., Zerbe, S., Gahlert, F., Mijit, M. and Succow, M. (2007) Productivity of Reed (Phragmites australis Trin. ex Steud.) in Continental-Arid NW China in Relation to Soil, Groundwater, and Land-Use. Journal of Applied Botany and Food Quality, 81, 62-68.

[17] Thevs, N., Buras, A., Zerbe, S., Kühnel, E., Abdusalih, N. and Ovezberdyyeva, A. (2012) Structure and Wood Biomass of Near-Natural Floodplain Forests along the Central Asian Rivers Tarim and Amu Darya. Forestry, 81, 193-202. http://dx.doi.org/10.1093/forestry/cpr056

[18] Wang, S.J., Chen, B.H. and Li, H.Q. (1996) Euphrates Poplar Forest. China Environmental Science Press, Beijing.

[19] Feng, Q., Liu, W., Si, J.H., Su, Y.H., Zhang, Y.W., Cang, Z.Q. and Xi, H.Y. (2005) Environmental Effects of Water Resource Development and Use in the Tarim Basin of Northwestern China. Environment Geology, 48, 202-210. http://dx.doi.org/10.1007/s00254-005-1288-0

[20] Zhang, J.B. (2006) Water Management Issues and Legal Framework Development of the Tarim Basin. In: Wallance, J. and Wouter, P., Eds., Hydrology and Water Law-Bridging the Gap: A Case Study of HELP Basins, IWA Publishing, London, 108-142.

[21] Hao, X.M., Chen, Y.N. and Li, W.H. (2009) Impact of Anthropogenic Activities on the Hydrologic Characters of the Mainstream of the Tarim River in Xinjiang during the Last Past 50 Years. Environment Geology, 57, 435-445. http://dx.doi.org/10.1007/s00254-008-1314-0

[22] Wang, R. (2009) An Empirical Analysis of Development of Water Rights in China. US-China Law Review, 6, 39-49.

[23] Lyle, C. and Mu, G.F. (2011) Integrated Management of the Tarim Basin, Xinjiang China. http://www.watertech.cn/english/clivelyle.pdf

[24] XPCC (2007) A Brief Introduction of XPCC. http://www.xjbt.gov.cn/publish/portal0/tab130/info25.htm

[25] TMB (Tarim Management Bureau) (2011) Report about the Reform of the Administration System of the Unified Management of the Tarim River Catchment. http://tahe.gov.cn/zhuanti/gaige/banner.html

[26] Tang, Q.C., Qu Y.G. and Zhou, L.C. (1993) Hydrology and Water Resource Utilization of Arid Land in China. China Science Press, Beijing.

[27] Zhou, L.C. (1999) River Hydrology and Water Resources of Xinjiang. Xinjiang Scientific Sanitation Press, Urumqi.

[28] Feng, Q. and Cheng, G.D. (1998) Current Situation, Problem and Rational Utilization of Water Resources in Arid North-Western China. Journal of Arid Environment, 40, 373-382. http://dx.doi.org/10.1006/jare.1998.0456

[29] Hedin, S.A. (1903) Scientific Results of a Journey in Central Asia 1899-1902, Vol. 1, The Tarim River. Lithografic Institute of the General Staff of the Svedish Army, Stockholm.

[30] Hsu, H.H. and Gale, F. (2001) Regional Shifts in China’s Cotton Production and Use. Economic Research Service/ USDA, Cotton and Wool Outlook/CWS-2001, 19-25.

[31] Xia, D.K. (1998) Dynamics and Water Resources of the Tarim River in Xinjiang. Journal of Arid Land Resources and Environment, 12, 7-14.

[32] Hoppe, T. (1992) Chinesische Agrarpolitik und Uygurische Agrarkultur im Widerstreit. Das Sozio-Kulturelle Umfeld von Bodenversalzungen und-Alkalisierungen im Nördlichen Tarim-Becken (Xinjiang). Institut für Asienkunde, Hamburg.

[33] Gries, D., Zeng, F., Foetzki, A., Arndt, S.K., Bruelheide, H., Thomas, F.M., Zhang X.M. and Runge, M. (2003) Growth and Water Relation of Tamarix ramosissima and Populus euphratica on Taklamakan Desert Dunes in Relation to Depth to a Permanent Water Table. Plant Cell Environment, 26, 725-736. http://dx.doi.org/10.1046/j.1365-3040.2003.01009.x

[34] Mao, X.H. (2001) Study on Sustainable Utilization Strategy of Water Resources in the Tarim Basin. Arid Land Geography, 24, 136-140.

[35] TMB (Tarim Management Bureau) (1997) Regulations of Tarim Basin on Water Resources Management. http://www.tahe.gov.cn/e/action/ShowInfo.php?classid=106\&id=4963

[36] World Bank (2007) Tarim Basin II Project. Report No. 41122. Sector, Thematic, and Global Evaluation Division Independent Evaluation Group, World Bank, Washington, 45-83. 
[37] TMB (Tarim Management Bureau) (2001) Report of Near-Future Comprehensive Management Program of the Tarim Basin. http://www.tahe.gov.cn

[38] TMB (Tarim Management Bureau) (2005) Scheme of Surface Water Distribution in the Tarim Basin (Four Source Streams and One Mainstream). http://www.tahe.gov.cn/e/action/ShowInfo.php?classid=106\&id=7375

[39] TMB (Tarim Management Bureau) (2005) Management Methods of Water Dispatching in the Tarim Basin (Four Source Streams and One Mainstream). http://www.tahe.gov.cn/e/action/ShowInfo.php?classid=106\&id=7377

[40] Water Law of the Peoples Republic of China. http://www.chinawater.net.cn/law/waterlaw.htm

[41] TMB (Tarim Management Bureau) (1999) Charter of the Tarim Basin Water Resources Commission. http://www.tahe.gov.cn

[42] Radosevich, G.E. (1999) Tarim Basin Case Study. IUCN Water Program NEGOTIATE Case Study. http://cmsdata.iucn.org/downloads/china_1.pdf

[43] Hofmann, S. (2006) Comparative Analysis of Uyghur and Han-Chinese Farm Management along the Middle Reaches of the Tarim River. In: Hoppe, T., Kleinschmit, B., Roberts, B., Thevs, N. and Halik, Ü., Eds., Watershed and Floodplain Management along the Tarim River in China's Arid Northwest, Shaker, Aachen, 359-371.

[44] Bothe, J. (2010) The Water Use of Cotton Cultivation in the Tarim Basin in Northwest China. Bachelor Thesis, University of Osnabrück, Osnabrück.

[45] Thevs, N., Zerbe, S., Schnittler, M., Abdusalih, N. and Succow, M. (2008) Structure, Reproduction and Flood-Induced Dynamics of Riparian Tugai Forests at the Tarim River in Xinjiang, NW China. Forestry, 81, 45-57. http://dx.doi.org/10.1093/forestry/cpm043. 